\title{
STUDENT REPRESENTATION AND THE RELATIONSHIP BETWEEN STUDENT LEADERS AND POLITICAL PARTIES: THE CASE OF MAKERERE UNIVERSITY
}

\author{
T. Mugume \\ Directorate for Institutional Research and Academic Planning \\ University of the Free State \\ Bloemfontein, South Africa \\ e-mail: mugumetj@ufs.ac.za
}

\section{T. M. Luescher}

Education and Skills Development

Human Sciences Research Council

Cape Town, South Africa

e-mail: tluescher@hsrc.ac.za

\section{ABSTRACT}

What are the characteristics and implications of the relationship between student leaders and national political parties in African universities? As the most prestigious university of Uganda, Makerere University represents a model case for investigating the involvement of political parties in student politics. Drawing on propositions adapted from Weinberg and Walker (1969), Schmitter and Streeck (1999), and others, this article uses data generated by means of in-depth interviews and an online survey to analyse the relationship between political parties and student leaders. It considers the reasons why student leaders and political parties establish a relationship; how it is maintained; and what its effects are on student leaders' ability to represent student interests. It finds that various kinds of resource exchange are key to understanding the relationship and considers its implications. The article concludes by recommending institutional interventions to curb the extent of resources that a party can provide to student leaders so as to contain the negative effects of the relationship while maintaining the potential for universities to act as 'training grounds' of democracy.

Keywords: higher education, student experience, student politics, university governance, political parties, democratisation

\section{INTRODUCTION}

Some of the earliest attempts at understanding the relationship between student politics and national politics in the wake of the student uprisings of the late 1960s included a focus on political parties. For instance, Weinberg and Walker (1969) found that partisan clubs of students and campus-based student branches of national parties provided systemic linkages between 
student politics, the higher education system, and the national political system. They argued that 'student branches of national political parties compete for student support in the struggle to control university government as well as to influence national politics' (Weinberg and Walker 1969, 81). Similarly, Andersen and Pant $(1970,942)$ showed that there was a close relationship between student politics and party politics in that party leaders influenced decisions on who should represent the party at university level in student elections. Overall the relationship was dynamic and beneficial to both, student leaders and party leaders. Thus, they argued that 'political parties [...] are used by student leaders who need money [e.g. during student election campaigns], present political support, as well as future political contacts to help them in their future political careers' (Andersen and Pant 1970, 943). Conversely, Hooghe, Stolle and Stouthuysen (2004) have emphasised the importance of students as youth recruits of national parties.

In the African context, research into the nexus of higher education and multiparty democracy involves many dimensions, including student politics (Mattes and LuescherMamashela 2012), which is important inter alia because 'investigations into student power and students' collective political behaviour contribute to a broader research theme of how human agency - individual and collective - shapes higher education policies, a theme which is still fairly underexplored within the field of higher education studies’ (Klemenčič, Luescher and Jowi 2015, ix). Most research in Africa has focused on student activism; only recently has scholarly attention turned to the study of student representation in higher education decisionmaking (Munene 2003; Luescher-Mamashela and Mugume 2014; Luescher, Klemenčič and Jowi 2016). Nonetheless, that partisan politics on African university campuses creates problems is well known, and a number of countries (such as Tanzania) and universities (such as the University of the Free State, South Africa) have prohibited partisanship in student elections (Soudien 2008; United Republic of Tanzania 2005). This response has been questioned, however. In the South African context, the report of the Ministerial Committee on Transformation and Social Cohesion and the Elimination of Discrimination in Public Higher Education Institutions (known as the 'Soudien Committee') argued in 2008 against a banning of political party activity in student politics:

It is arguable whether the depoliticisation of student governance would necessarily yield the end result desired by institutions. Indeed, it is likely to intensify tension and conflict between student organisations and management on the one hand, and between student organisations and non-partypolitical SRCs on the other. More importantly, however, disallowing student political organisations is an infringement of the constitutional right to freedom of association and could be regarded as unfair discrimination. (Soudien 2008, 110-111) 
In the Ugandan context, studies of student politics at Makerere University (MAK) indicate a historical relationship between student leaders and political parties at that university, and they highlight some aspects to take into account when seeking to understand the ways in which partisanship relates to student politics (Byaruhanga 2006; Mugume and Katusiimeh 2016). Studying the way partisan relationships between student leaders and political parties are established and maintained, and what their impact is on institutionalised student politics, is therefore an important part of seeking to understand higher education politics and its relation to higher education policy and the broader body politic.

\section{RESEARCH APPROACH}

Several recent studies into the nature of student representation in various higher education contexts have adapted a framework that was initially designed to study the organisational dynamics of business interest associations (BIA). Schmitter and Streeck (1999) developed a framework to understand why independent business investors in industrialised countries come together to protect and represent their interests in BIA. Schmitter and Streeck's heuristic framework includes a typology of four types of associative actions. Parts of this framework have been adapted by Jungblut and Weber (2012) to study the development of the German student union; Klemenčič (2012) adapted it for her study of student representation in Europe; and Luescher-Mamashela and Mugume (2014) proposed an adapted version for studying partisan student politics in Africa. In the latter adaptation, political parties take the place of BIAs with which student leaders freely associate. A key variable in different associative actions is the type and level of resource exchange between student leaders and parties, the significance of which has been pointed out earlier by Andersen and Pant (1970).

Against this, the present study investigates the general proposition that resource exchange between student leaders and political parties is a key factor for understanding why partisan relations are established and how they are maintained, and the impact of partisanship on student representation. The related research questions are therefore:

(1) What are the reasons for student leaders and political parties to establish relationships?

(2) What arrangements are required to maintain these relationships?

(3) What are the implications of partisan relations for student leaders' ability to represent student interests?

The first two questions focus specifically on the exchange of resources involved in establishing 
and maintain partisan relations; the third question considers the impact of partisanship on student leaders' ability to represent student interests. With respect to the latter, the Soudien Committee painted a potential scenario where partisan student leaders would become 'too focused on national political issues and not on serving and/or representing the interests of students on campus' (2008, 109-110).

\section{METHODOLOGY}

In-depth empirical research was conducted at MAK during the 2013/14 academic year. MAK offered itself as a good case for an in-depth study based on a number of criteria. The university was established in 1922 as Uganda’s first post-secondary college; it is today Uganda's flagship university and the highest ranked African university outside of South Africa (Bothwell 2015; Makerere University Annual Report 2013, 8). MAK is also the largest university in the country. In 2013/14, MAK had a student body of 36,516 students of which over 90 per cent were undergraduate students. Furthermore, Makerere has a documented historical and on-going relationship with political parties and role in the formation of the national elite (Alina 2014; Byaruhanga 2006).

The study used a mixed methods quan-qual approach (cf. Creswell 2003) whereby an online survey was carried out in 2013/14 to gather the perceptions of a large sample of undergraduate students and student leaders on the topic. The survey produced a total of 941 responses of undergraduate students including a subsample of 109 student leaders. The survey was part of a larger pilot study by the Higher Education Research Advocacy Network in Africa (HERANA) into the relationship between higher education and democracy (see LuescherMamashela 2015). It therefore did not produce a fully representative sample. Details on the methodology, reliability and validity of the survey, and representivity of the sample are documented in Luescher-Mamashela (2015, 26-32).

Subsequent to the analysis of survey responses, in-depth interviews were conducted with student leaders, the dean of students of MAK, and party representatives in charge of the student or youth portfolio from the four most important national political parties of Uganda (i.e. the ruling National Resistance Movement/NRM; the Forum for Democratic Change/FDC, which is the largest opposition party; the Democratic Party/DP, and the Uganda People's Congress/UPC, which are the two oldest parties). Overall, twelve interviewees were purposefully selected for their involvement in, and in-depth knowledge of, partisan student politics at MAK (seven party leaders, four student leaders, and the dean). Using this method, survey responses could be explored in greater depth. 


\section{STUDENT REPRESENTATION AT MAKERERE UNIVERSITY}

Provided that Makerere is the premier university of Uganda, the effects of national politics on MAK have always been felt strongly (Sicherman 2005). While Makerere students have historically been criticised for having been less involved in politics - and particularly in the struggle for independence - than students elsewhere in Africa, Byaruhanga (2006) has shown a close relationship between student leadership and national government, and student leadership and the major political parties in Uganda. Indeed, the relationship is strikingly close. According to Byaruhanga (2006), the resolution of most student protests involves State House i.e., the Office of the President. Student boycotts frequently end up in a call or visit by Uganda's President to the university and the President making certain promises before protests end. In this respect, Byaruhanga has argued that the ruling party is more inclined to make concessions when the incumbent student guild president is a member of the NRM. National government's response to student demands at Makerere is therefore conditioned by student leaders' partisanship.

There are several party chapters or branches at MAK which are geared towards recruiting students and supporting student leaders. They include branches of the NRM, FDC, UPC as well as the Uganda Young Democrats (UYD) which is a youth branch of the DP. Many of the members of the Makerere student government, i.e. the student guild, are affiliated to one of these party chapters. Opposition parties are more popular among students, while the ruling NRM has been struggling to gain strong student support throughout its more than 25 years of reign. Thus, the guild presidency at MAK has been mostly won by UYD and FDC candidates. (Interviews with guild leaders, October 23 and 24, 2013)

\section{Structures of student representation}

The Guild Representative Council (GRC) is at the centre of student governance. It constitutes the university's student parliament from where the guild president draws her/his cabinet. The 96 GRC representatives are elected from different constituencies, especially the halls of residences (including resident and non-resident students), colleges and schools of the university, and the games union.

The guild president, who is directly elected by students in an annual partisan student election, formally heads all student governance structures. He or she appoints the 28 members of the guild cabinet (referred to as 'ministers') from the GRC. The guild cabinet thus refers to the executive student representative body of MAK; it is formally responsible for articulating 
and intermediating the interests of students within the institution, in university governance committees, and nationally (Interviews with guild leaders and dean of students, October 23 and 24, 2013; Makarere University Guild Constitution 2011).

Students are formally represented in the university's council and senate, as well as in a number of committees of these bodies. Council committees with student representation include: the finance planning and academics committee, the students welfare and disciplinary committee, the quality assurance committee (a joint committee), and the estates and works committee. Senate committees with student representation include: the admissions board, the research committee, the quality assurance committee (a joint committee), the appeals committee (an ad hoc committee), and the anti-sexual harassment committee. The committees typically have one or two student representatives who are appointed with due consideration of gender equity and the representation of disabled students (Interview with dean of students and guild leaders, October 23, 2013). It is by means of this formal system of student representation, informal meetings with the university leadership, and occasional protest action, that student leaders voice students’ interests.

\section{Student guild electoral process}

The main student election at MAK is the annual election of the guild president. The electoral process is determined in the MAK Guild Constitution (2011) which provides for the election to be overseen by an electoral commission made up of students and a staff member. Candidates for the presidency customarily go through highly public party primaries on campus up to the point where one party member is elected as a party's flag bearer in the upcoming elections; other contenders may stand as independents (Alina 2014). After about three weeks of campaigning, the election is held campus-wide, and all registered MAK students are free to vote. The winner of the presidency will then appoint members from the GRC to form a cabinet. With regard to the GRC campaigning and elections take place at the same time as the presidential election. (Interviews with guild leaders, October 23, 2013)

The electoral process and structure of student government have been designed to resemble the national process and structures, where the presidential candidate first contests party primaries (or can stand as independent) after which a nation-wide direct election follows. The president-elect then appoints a cabinet from members of the national parliament. The Ugandan parliament is composed of members from demarcated constituencies, some of which are geographical and determined by population size, while others represent structures such as the police and the army (Electoral Commission of Uganda 2013). The corresponding design 
provides for student leaders to learn how electoral politics operates at national level including the significance of party politics in national elections.

\section{STUDENT LEADERSHIP AND POLITICAL PARTIES AT MAKERERE UNIVERSITY}

The survey conducted with undergraduate students at MAK shows that a large proportion of both, student leaders and students not in leadership have partisan affiliation, and many are actively involved in their respective party chapters on campus. Figure 1 shows that about 3 in 5 student leaders are party members ('official leader' 11\%, 'active member' 31\%, 'inactive member' 18\%), and 2 in 5 of ordinary students ('official leader' 2\%, 'active member' 22\%, 'inactive member’ 17\%). It is especially noteworthy that 1 in 10 student leaders (11\%) report being recognised as part of the party leadership.

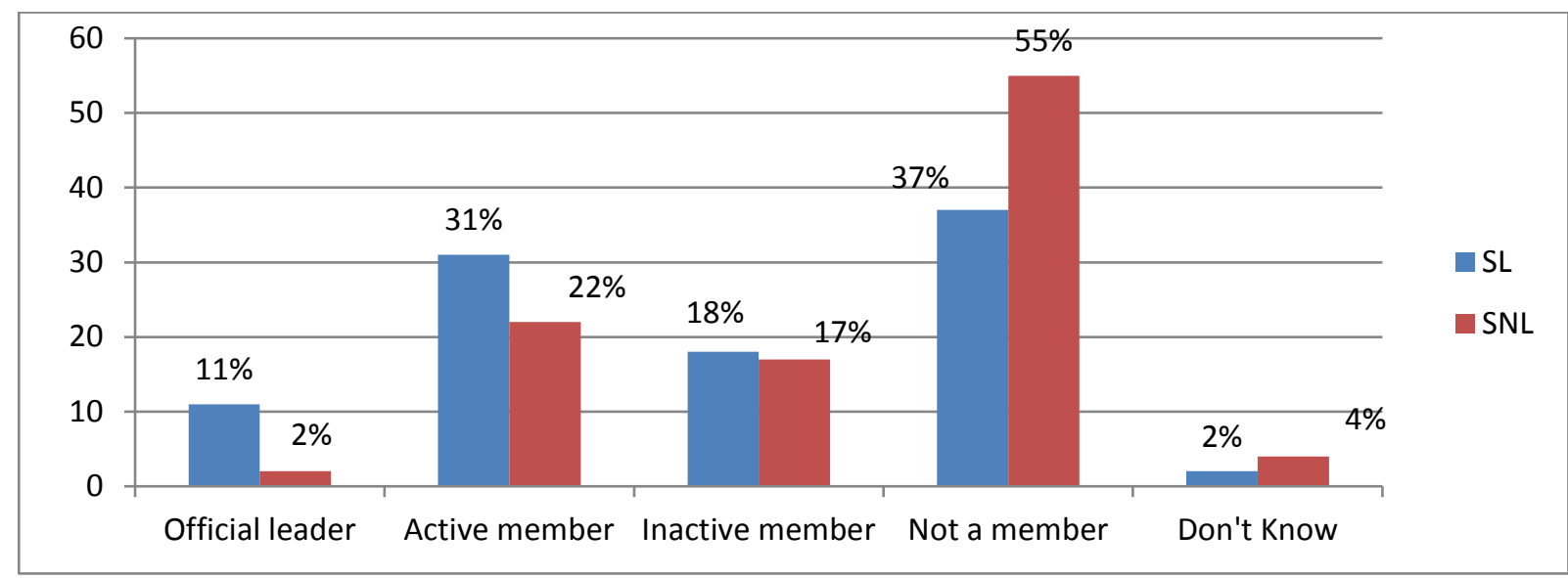

Key: $\mathrm{SL}=$ student leader; $\mathrm{SNL}=$ student not in leadership $\mathrm{N}$ for $\mathrm{SL}=109$, Missing=8; $\mathrm{N}$ for $\mathrm{SNL}=832$, Missing=79.

Figure 1: Student involvement in political party chapters on campus

Overall the impression from the survey is that a large proportion of students at MAK hold party membership, and that student leaders tend to be more likely and more intensively involved in political parties than ordinary students. Partisanship is overall surprisingly widespread on campus.

The survey data in Figure 1 also corresponds with earlier findings that political parties focus on student leaders, especially guild election candidates as recruits, and that there is a correlation between student leadership and the leadership of the party chapters at MAK. Even though political parties are known to target guild presidency candidates, other student leadership candidates cannot just ignore party support given the resources some candidates receive during student election campaigns. According to guild leaders, it is only 'wise' for any 
student leadership candidate to try and associate him or herself with a party. While independent candidates can stand for the guild presidency, it is typically candidates affiliated with political parties who win (Interviews with guild leaders, October 23 and 24, 2013). Indeed, when a socalled independent candidate wins, such a candidate will have turned independent only because of conflicts within his or her party chapter. This occurs when a candidate believes that the party primaries had not been free and fair, and that he or she lost being the party flag-bearer to another candidate due to some foul-play. In other words, not just any individual who runs as independent without any party connections can win (Interviews with guild leaders, October 23 and 24, 2013). Provided that the MAK survey was a pilot and did not produce a fully representative sample, the statistical significance of this correlation has not been tested but is proposed here as hypothesis for future studies of this nature.

The pressure to affiliate to a political party starts early for guild presidency aspirants. The interviewed guild leaders confirmed a range of ways in which political parties support candidates. Firstly, the party provides campaigners and supporters for a candidate's campaign. They are typically its staunchest members and will work for the candidate during the campaign playing various roles. A candidate for the guild presidency needs to have a strong team of party supporters who create a positively inspiring image in the candidate's camp (Interview with guild leader B, October 23, 2013). In addition, a candidate is able to access party logistics, finances and campaign expertise, which are extremely important, especially in campaigns for the presidency. This observation is confirmed by Oanda (2016) who argues that leading political parties in Uganda wield a lot of influence because the electoral campaigning at MAK is 'heavily monetised':

Guild campaign candidates are expected to dress up, drive fancy cars, and be accompanied by a convoy of equally ostentatious looking vehicles as they move from hall to hall to campaign. They are expected to provide music at the venues, print posters, and provide beverages and alcohol to their supporters. All these cost a lot of money. (Oanda 2016, 79-80)

Campaigns for the presidency require and receive a lot of party support; this is less so for GRC campaigns, given that the positive impact for the party - in particular the prestige for having a party member as incumbent - is small. Moreover, at the level of GRC elections, the student electorate tends to be more concerned about the personal qualities of the candidate, rather than her or his affiliation. Conversely, the Makerere guild presidency election is national news. Both, the student leaders and party leaders interviewed for this study confirmed that Ugandan political parties recognise the importance of the youth in the country, and given Makerere's status in the country, the youth generally aspire to it and seek to associate themselves with it; hence the 
national popularity of its guild president (Interviews with guild leaders A and B, October 23, 2013; FDC leader A, October 22, 2013).

In addition to the costs of campaigning, aspirations of getting involved in national politics have been cited among the key reasons why student leaders seek to establish a relationship with a party. Evidence from interviews shows that many student leaders at MAK expect that associating with a party will serve their future career ambitions in politics. That there is some substance to these expectations has been noted by Byaruhanga (2006) who found that some MAK student leaders have historically ended up as powerful politicians or in powerful bureaucratic positions. The rewards that a student leader may expected from this kind of relationship cannot easily be ignored; thus, student leaders who aspire to a future political career will ensure they establish a good relationship with a party and participate in maintaining it (Interviews with guild leaders A and B, October 23, 2013). This is discussed further with reference to Table 4.

Furthermore, a variety of arrangements exist which political parties seek to accommodate student leaders and their concerns within party structures. There is a good awareness of such structures among MAK student leaders: 3 in 4 of the surveyed student leaders (67\%) are aware that their party has a youth wing office; just over 3 in 5 student leaders (62\%) refer to a special student desk in the party to handle student leaders' issues; and almost half (49\%) claim that student leaders 'like me' are not considered ordinary members but hold a leadership position within their party (compare Figure 2).

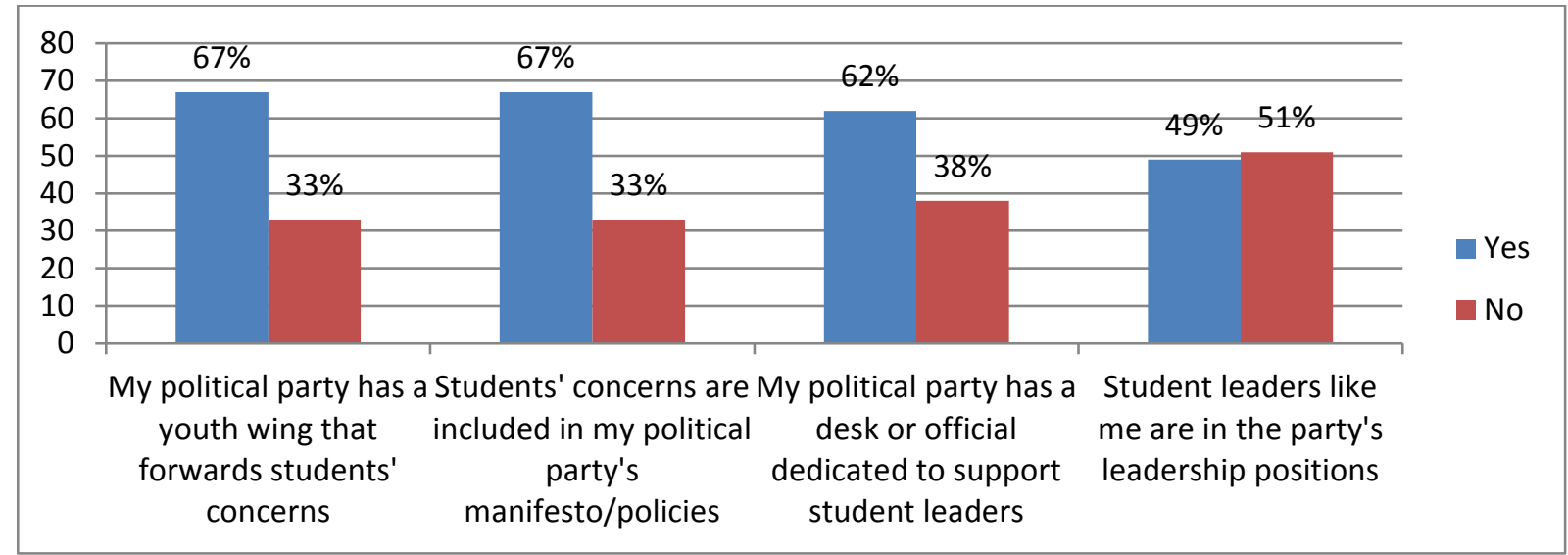

$\mathrm{N}=109$, Missing=47 ( $\mathrm{N}=$ Student leaders only)

Figure 2: Does your political party represent student leaders' concerns?

The perceived efficacy of party-internal arrangements to accommodate, reflect and shape student leaders' interests, and provide for structures to support them, is evident in the large proportion of student leaders ( 3 in $4 ; 67 \%$ ) who opine that student issues are included in their 
respective political party’s manifesto and policies.

\section{MAINTAINING THE RELATIONSHIP BETWEEN STUDENT LEADERS AND POLITICAL PARTIES}

Resource exchange is a characteristic found in all associative actions proposed by LuescherMamashela and Mugume (2014), operating in different directions and at varying degrees. Tables 1, 2, 3 and 4 show empirically what kinds of resources are provided and how, at different stages of a students’ life-cycle as student leader.

Table 1: What support do you get from a political party for your election campaign?

\begin{tabular}{|l|l|l|}
\hline $\begin{array}{l}\text { The various goods and services } \\
\text { provided to SL during campaigns }\end{array}$ & $\begin{array}{l}\text { Actual number of SL who agree to having } \\
\text { received these goods and services }\end{array}$ & Percentage \\
\hline Posters & 30 & 28 \\
\hline Cash for campaigning & 23 & 21 \\
\hline Training in campaigning & 20 & 18 \\
\hline Rallies & 19 & 17 \\
\hline Writing a manifesto & 13 & 12 \\
\hline T-shirts & 10 & 9 \\
\hline
\end{tabular}

$\mathrm{N}=109$ (student leaders). This was a multiple response question. Respondents could select as many options as they liked. Therefore, each choice response is to a total of $100 \%$.

Table 1 shows the type of resource that sampled student leaders have actually received from their party chapter for the 2013/14 election campaign period. Almost 1 in 3 received posters (28\%); about 1 in 5 received cash for campaigning and/or campaign training; 1 in 6 had campaign rallies organised for them, and about 1 in 10 received support in writing their manifesto and/or T-shirts as part of the party’s campaign support. While respondents could chose multiple forms of party support, the various percentages only about add up to 100 per cent; thus if each student leader was only given one type of support, every leader would have received a party resource of some kind for campaigning. This is unlikely however; rather it is clear that few student leaders in the sample received a large variety of goods and services while others received none. Interviewees have stressed that political parties focus on guild leadership campaigns and on the guild presidency candidates in particular to provide campaign support; meanwhile, the respondents also include college and school representatives, GRC members, and guild cabinet members (also see: Interview with UPC leader B, October 17, 2013; Interview with FDC leader A, October 22, 2013; Interview with guild leaders A and B, October 23, 2013). Moreover, as shown previously (Figure 1), about 40 per cent of student leaders are not affiliated to any party. Looking at Table 1, it therefore shows a serious interest and investment by political parties in a select few student leaders, i.e. typically the candidates for the guild presidency. A 
UPC leader argued that the focus on the guild presidency was largely due to a shortage of party funds; even though the party always intends to support and encourage young leaders, it is strained for resources (Interview with UPC leader A, October 17, 2013).

After a student leader has been elected into office, maintaining the relationship again involves a variety of resources from parties (or student leaders' expectation thereof). Thus, Table 2 shows that almost 2 in 5 of the sampled student leaders (37\%) expect ongoing leadership training and workshops, and about 1 in 6 expect political support from the party in terms of using its influence with university management or national government. There are also continued expectations for material support: just over 1 in 7 hope to land an internship through their party connection, and a small number of about 1 in 20 expect cash support and/or scholarship funds for tuition or residence (Table 2).

Table 2: What support do you expect from a relationship with a political party when elected in student leadership office?

\begin{tabular}{|l|l|l|}
\hline $\begin{array}{l}\text { The various goods and services that could be } \\
\text { provided to SL after elections }\end{array}$ & $\begin{array}{l}\text { Actual number of SL who } \\
\text { agree }\end{array}$ & Percentage \\
\hline Leadership training and workshops & 40 & 37 \\
\hline The party can put pressure on university management & 18 & 17 \\
\hline Internship & 16 & 15 \\
\hline The party can put pressure to change national policies & 16 & 15 \\
\hline Cash support during studies & 6 & 6 \\
\hline Tuition or residence funding/scholarship & 5 & 5 \\
\hline
\end{tabular}

$\mathrm{N}=109$. This was a multiple response question. Respondents could select as many options as they liked.

Therefore, each choice response is to a total of $100 \%$.

Thus, student leaders' expectation of goods and services from their party does not stop after their election, even if the flow of cash and other material goods is expected to wane and turn more towards political support and services. The party's actual provision of services to incumbents is not only meant to contribute to the development of the young leaders but also to coach them to perform well in office to send a favourable message about the party's brand (Interview with FDC leader A, October 22, 2013). Again, Table 2 shows that only a few student leaders expect to be provided with such resources, possibly for reasons discussed in relation to Table 1.

Finally, many student leaders do not expect the relationship with their party inaugurated while studying at MAK to end after graduating. Over 1 in 3 expect their party affiliation to pay off in terms of career opportunities (34\%); and between 1 in 5 and 1 in 4 student leaders expect to get a job in local or national government (18\%), a leadership position in the party (23\%), and/or to be selected to stand on a party platform in a constituency as candidate (26\%) (Table 3). 
Table 3: What support do you expect from a relationship with a political party once you have graduated?

\begin{tabular}{|l|l|l|}
\hline $\begin{array}{l}\text { The various goods and services to be provided to SL } \\
\text { after graduating }\end{array}$ & $\begin{array}{l}\text { Actual number of SL who } \\
\text { agree to the option }\end{array}$ & Percentages \\
\hline Career opportunities & 37 & 34 \\
\hline Selection to stand on party platform in a constituency & 28 & 26 \\
\hline Leadership position within the party & 25 & 23 \\
\hline Job in local or national government & 20 & 18 \\
\hline
\end{tabular}

$\mathrm{N}=109$. This was a multiple response question. Respondents could select as many options as they liked. Therefore, each choice response is to a total of $100 \%$.

These are clearly high expectations that student leaders have of professional and/or political career opportunities on party affiliation. What do the political parties get out of their relationship with student leaders?

Table 4: What does your political party expect from you as a party member and student leader?

\begin{tabular}{|l|l|l|}
\hline The various options a SL could choose & $\begin{array}{l}\text { Actual number of SL who } \\
\text { choose the option }\end{array}$ & Percentages \\
\hline Participation in political party activities & 40 & 37 \\
\hline Recruiting new members & 36 & 33 \\
\hline Being a disciplined member of the party & 30 & 28 \\
\hline Volunteering time and effort & 30 & 28 \\
\hline Publically defending the party's position & 25 & 23 \\
\hline Including party branding in your campaign & 21 & 19 \\
\hline Including party position and ideology in your manifesto & 20 & 18 \\
\hline
\end{tabular}

$\mathrm{N}=109$. This was a multiple response question. Respondents could select as many options as they liked. Therefore, each choice response is to a total of $100 \%$.

Table 4 demonstrates the expected obligations of student leaders towards their party (from the point of view of student leaders). It shows that about 1 in 3 student leaders feel obligated to participate in party activities (37\%), recruit new members (33\%), be disciplined party members (28\%), and volunteer their time and effort in various ways (28\%). Student leaders who hope to continue a strong relationship with their party upon graduation and stand on a party platform in a constituency in the future (see Table 3 above) seek to solidify their party connection by getting involved in the party structures in their home areas. Furthermore, almost 1 in 4 expect to publicly defend the party's position (23\%), and almost 1 in 5 think that their party expects them to include party branding in their campaign (19\%) and include party positions and ideology in their manifesto (18\%).

The recruitment of new party members is another expectation that student leaders are acutely aware of. Table 4 shows that 1 in 3 student leaders mention it as a party expectation (33\%). Recruiting new members from the student body is an important way for a party to renew itself and gain members with competences that may be useful (FDC leader A, October 22, 2013; Guild leaders A and B, October 23, 2013; UPC leaders A and B, October 17, 2013). This point 
has also been made in very different contexts by Hooghe et al. (2004), Rochford (2014) and much earlier by Weinberg and Walker (1969).

It is noteworthy that overall more student leaders indicate what they should give back to their party than what they receive from their party (compare Table 4 with Tables 1-3). Moreover, while political parties provide both goods and services to student leaders, student leaders mostly promise services and loyalty to their party (Interviews with student leader A, October 23, 2013 and UPC leader B, October 17, 2013). The actual and expected exchange of resources is evidently important in the process of establishing and maintaining the relationship between student leaders and political parties.

\section{THE IMPACT OF PARTISANSHIP ON STUDENT INTEREST REPRESENTATION}

The perception of student leaders' ability to represent student interests may be influenced by various factors. As far as this study is concerned, the survey data shows that a majority of ordinary students and student leaders argue that partisanship impacts negatively on student representation. Almost 3 in 4 students not in leadership agree at least somewhat that there is a negative impact (72\%); an even greater proportion of over 3 in 4 student leaders agree that the relationship is detrimental to student representation (76\%).

In interviews, different reasons have been given for these negative perceptions. The dean of students of Makerere argued that political parties were 'commercialising' student politics at his university and that student leaders ended up paying more attention to national political problems linked to party policy positions than to campus issues (Interview, October 23, 2013). The argument that political party issues overshadow university and student-specific issues in student representation was also heard in other interviews. A guild leader, for instance, concurred that 'we do a lot of politicking [...], all the talking but very little action' (Interview with guild leader D, October 24, 2013), while others argued that aspirations of a future political career called for compromises which may not be in the interest of the student body as a whole (Guild leaders B and C, October 23, 2013 and 24, 2013). Partisan affiliation may directly impact on student interest representation as this guild leader reports:

We have had programmes; programmes which in my opinion were non-partisan. [However,] the guild president found it hard to be part of [the programmes] yet they were benefiting students. But because these are believed to be NRM programmes, the guild president somehow decided to scrap or dodge them because she thinks, what will the party [i.e. FDC] think of her? ... (Interview with guild leader D, October 24, 2013).

Thus, political parties have sway over student leaders so much so that programmes that could 
help students are discontinued if they are perceived to be of another party. This same point was confirmed by another student leader who argued that the guild leadership had been invited to participate in government programmes that could be beneficial to students, 'but because they are organised by the NRM, the invitations never reach all the guild leaders, they get stuck on someone’s desk, you know' (Interview with guild leader C, October 24, 2013). Similarly, meetings with high level officials are avoided so as to be perceived as party loyal. A guild cabinet minister argued that:

The system we have here grooms us for the future, but it does not benefit the students we lead at this point. We are looking more ahead [towards national politics] rather than to work and solve students’ problems here ... (Interview with guild leader C, October 24, 2013).

There is therefore a strong sense of obligation towards the party, more especially if a student leader has political and professional career ambitions linked to her or his party. Student leaders will avoid issues which they think can antagonise their party, and seek to please the party in a constant balancing act between being seen to represent student interests and being a loyal youth cadre of their party. It is in this respect then that party politics may be seen to be compromising student representation and to negatively impact on the ability of student leaders to actually represent students. Student leaders must by all means avoid being seen as 'compromised leaders'. The notion of becoming 'compromised' as a student leader has been mentioned in several interviews. For instance, we were told that the guild president 2013/14, who was an affiliate of the oppositional FDC, avoided having formal meetings with leaders from other parties and even declined to meet the President of Uganda on occasion (who is also the leader of the NRM), precisely for fear of being seen by FDC as potentially 'compromised' (Interview with guild leaders A and B, October 23, 2013).

The negative perceptions regarding the impact of partisan relations on student leaders' ability to represent student interests are seemingly at odds with other evidence presented both in the survey and in interviews. For instance, Figure 3 shows reasonably high levels of trust between students and student leaders: 2 in 3 ordinary students trust student leaders (somewhat/a lot); which is about the same that student leaders trust each other. This reflects positively on the student leadership at MAK, especially when considering much lower levels of trust found in earlier studies at the universities of Nairobi, Dar es Salaam and Cape Town (LuescherMamashela 2010, 13). Thus, it would appear that in terms of the students' perceptions of trust, the relationship between student leaders and political parties has little impact. 


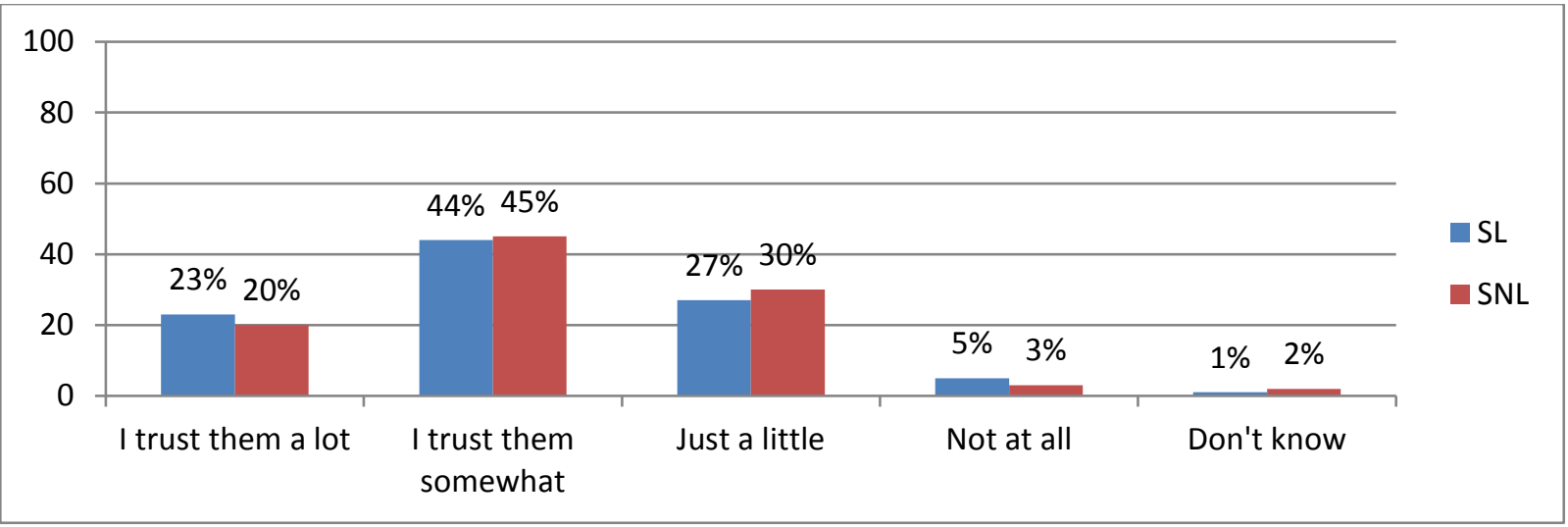

$\mathrm{N}$ for $\mathrm{SL}=109$ and Missing=2; N for SNL=832 and Missing=64.

Figure 3: How much do you trust student leaders at Makerere University?

Moreover, it is argued that training student leaders in democratic politics is one of the benefits of partisan relations. A sizeable majority of 3 in 4 students and student leaders agree or strongly agree in the survey that 'the relationship between student leaders and political parties affords student leaders an opportunity to be trained in democratic politics' (76\% of ordinary students; $74 \%$ of student leaders). Training in democratic politics may help student leaders to represent student interests better.

Finally, in seeking to understand the negative survey responses considering the impact of partisan relations on student leaders' ability to represent students, guild leader B (Interviewed, October 23, 2013) argued that the reported negative implications were in most cases exaggerated. The student leader argued that to be a leader at MAK, one must first and foremost be popular among students. As soon as a student leader turns against student interests, she or he will lose popularity and so will her/his party. The interviewee's claim is therefore that both, student leaders and parties will always seek to safe-guard the interests of students for the sake of their popularity. In extension of this, a party leader argued in an interview:

... Party leaders are not aiming for party interests but rather student interests, and guild student [leaders] are Ugandans like any other Ugandan. So if the interests of the FDC party are bad, Adeke [i.e. the 2013-2014 guild president] would not be guild president. Therefore ... those who do think she does represent students' interests are part of what we stand for (Interview with FDC leader A, October 22, 2013).

Thus, albeit from different perspectives both the guild student leader and the party leader of the FDC argue that there is a convergence of interests between students and parties.

\section{IMPLICATIONS AND CONCLUSION}

Corresponding with the reintroduction of multiparty politics in most African countries in the 1990s, student politics in African universities has become deeply party-politicised. This case 
study of student politics at Makerere University provides a basis for understanding the characteristics and implications of partisan affiliations of student leaders at different stages in the student political process. It shows that relationships between political parties and student leaders are typically established and solidified in the run up to and during electoral campaigns for key positions in student government; maintained during student leaders' term of office; and frequently expected to continue after graduation. Their transactional nature - involving both actual and expected resource exchanges - is a key characteristic of the relationship and has ambiguous effects on student leaders' ability to represent students. On the one hand, a student electoral and governance system that mirrors 'big politics' offers important lessons about democratic multiparty politics in the microcosm of campus life. Together with the training that political parties afford student leaders, this supports the civic function of universities as 'training grounds' in democracy and augment trainings offered by departments of student affairs. In the process, political parties benefit by gaining platforms to popularise their manifestoes and renew their membership, and thus gain well-educated members who are eager to offer their services.

On the other hand, the transactional nature of partisan relations in student politics has many negative implications for higher education. Student leaders' sense of 'indebtedness' to their party and hopes for future benefits may lead them to act contrary to their mandate as representatives of students. They need to profile themselves as loyal party stalwarts and avoid being seen as 'compromised'. Their involvement with party politics may significantly alter their student experience. In this regard, partisan relations may threaten the key element in the representation of the student voice and source of legitimacy of student representatives in higher education policy-making: the correspondence of the experiences and interests of student leaders and ordinary students (Klemenčič et al. 2015).

It is therefore advisable that higher education institutions such as universities investigate how best to enhance positive dimensions of partisan student politics like political learning, leadership training, and greater political transparency, while regulating the negative dimensions. Limiting the extent to which political parties are allowed to supply material resources and services to student leaders during election campaigns and thereafter (as part of a transparent electoral code and student leaders' code of conduct) would thus provide an important intervention.

\section{REFERENCES}

Alina, M. 2014. New Electoral Commission prepares for Guild polls: Guild Electoral Commission. http://news.mak.ac.ug/2014/02/new-electoral-commission-prepares-guild-polls (accessed 25 
February 2014).

Andersen, W. and A. Pant. 1970. Student politics at Allahabad University II. Economic and Political Weekly 5(24): 941-948.

Bothwell, E. 2015. Top 30 African universities: Times Higher Education reveals snapshot university ranking. Times Higher Education. https://www.timeshighereducation.co.uk/news/top-30-africanuniversities-times-higher-education-reveals-snapshot-university-ranking (accessed 31 July 2015).

Byaruhanga, F. K. 2006. Student power in Africa's higher education: A case of Makerere University. New York: Routledge.

Creswell, J. W. 2003. Research design: Qualitative, quantitative and mixed methods approaches. Thousand Oaks: Sage Publications.

Electoral Commission of Uganda. 2013. Election Results. http://www.ec.or.ug/eresults.php (accessed 11 December 2013).

Hooghe, M., D. Stolle and P. Stouthuysen. 2004. Head starting in politics: The recruitment function of youth organisations of political parties in Belgium (Flanders). Party Politics 10(2): 193-212.

Jungblut, J. and R. Weber. 2012. National student governance in Germany: The case of fzs. European Journal of Higher Education 2(1): 47-62. DOI:10.1080/21568235.2012.683701.

Klemenčič, M. 2012. Student representation in Western Europe: Introduction to the special issue. European Journal of Higher Education 2(1): 2-19. DOI:10.1080/21568235.2012.695058.

Klemenčič, M., T. M. Luescher and O. J. Jowi. 2015. Student power in Africa: Introduction. Journal of Student Affairs in Africa 3(1): vii-xiv. DOI:10.14426/jsaa.v3i1.99.

Luescher, T. M., M. Klemenčič and O. J. Jowi. (Eds.). 2016. Student politics in Africa: Representation and activism. Cape Town and Maputo: African Minds.

Luescher-Mamashela, T. M. 2010. Student perceptions of student leadership: Involved, responsive, corrupt. Presentation made at the African Student Leaders' Summit, 8 September 2010. http://www.chet.org.za (accessed 20 March 2012).

Luescher-Mamashela, T. M. 2015. The impact of student engagement on citizenship competences. Cape Town: CHET.

Luescher-Mamashela, T. M. and T. Mugume. 2014. Student representation and multiparty politics in African Higher Education. Studies in Higher Education 39(3): 500-515. DOI: 10.1080/03075079.2014.896183.

Makerere University Annual Report. 2013. Annual Report. http://www.muwrp.org/wpcontent/files/Makerere-University-Annual-Report-2014x.pdf (accessed 20 June 2014).

Makerere University Guild Constitution. 2011. http://policies.mak.ac.ug/sites/default/files/policies/ GUILD\%20CONSTITUTION\%20NEW.pdf (accessed 11 May 2014).

Mattes, R. and T. M. Luescher-Mamashela. 2012. The roles of higher education in the democratisation of politics in Africa: Reports of HERANA Studies. Journal of Higher Education in Africa 10(1): 139-170.

Mugume, T. and M. W. Katusiimeh. 2016. Private higher education and student representation in Uganda: A comparative analysis of Makerere University and Uganda Christian University. In Student politics in Africa: Representation and activism, ed. T. M. Luescher, M. Klemenčič and J. Jowi. Cape Town and Maputo: African Minds.

Munene, I. 2003. Student activism in African higher education. In African higher education: An international reference handbook, ed. D. Teferra and P. G. Altbach, 117-27. Bloomington: Indiana University Press.

Oanda, I. 2016. The evolving nature of student participation in university governance in Africa: An overview of policies, trends and emerging issues. In Student politics in Africa: Representation and activism, ed. T. M. Luescher, M. Klemenčič and O. J. Jowi, 62-85. Cape Town and Maputo: African Minds. 
Rochford, F. 2014. Bringing them into the tent - student association and the neutered academy. Studies in Higher Education 39(3): 485-499. DOI:10.1080/03075079.2014.896184.

Schmitter, P. C. and W. Streeck. 1999. The organisation of business interests: Studying the associative action of business in advanced industrial societies. MPIfG Discussion Paper 99(1). http://www.econstor.eu/bitstream/10419/43739/1/268682569.pdf (accessed 20 January 2014).

Sicherman, C. 2005. Makerere 1922-2000: Becoming an African university. Kampala: Fountain Publishers.

Soudien, C. 2008. Report of the Ministerial Committee on Transformation and Social Cohesion and the Elimination of Discrimination in Public Higher Education Institutions. 30 November. Pretoria: Department of Education.

United Republic of Tanzania. 2005. Universities Act 2005. Act No. 7/2005. http://parliament.go.tz/ polis/uploads/bills/acts/1452174215-ActNo-7-2005.pdf (accessed 4 March 2016).

Weinberg, I. and K. N. Walker. 1969. Student politics and political systems: Toward a typology. American Journal of Sociology 75(1): 77-96. 